증 례

$$
\text { 기 관지경으로 확진한 기관지내 연골성 과오종 } 1 \text { 예 }
$$

한양대학교 의대대학 내 과학교실

$$
\begin{gathered}
\text { 이성구 · 이민교 - 김홍근 · 김태화 } \\
\text { 이동후 · 박성수 · 이정희 }
\end{gathered}
$$$$
\text { 병 리 학 교 실 }
$$

이 중 달

$=$ Abstract $=$

\title{
Endobronchial Chondroid Hamartoma of the Lung -Case Report-
}

Sung Koo Lee, M.D., Min Kyo Lee, M.D., Hong Keun Kim, M.D., Tae Hwa Kim, M.D.

Dong Hoo Lee, M.D., Sung Soo Park, M.D. and Jung Hee Lee, M.D.

Department of Internal Medicine, Hanyang University, College of Medicine

Jung Dal Lee, M.D.

Department of Pathology

Hamartomas can occur in any organ of the body, the characteristic feature being that they are composed of disorganized elements of tissue normally present in that particular organ.

Althought pulmonary hamartomas are not uncommon, those which are intrabronchial or multiple are rare.

A correct preoperative diagnosis of endobronchial hamartoma is infrequently made.

Rarely adequate tissue can be obtained through the bronchoscope, but usually thoracotomy is required.

This is a report of endobronchial chondroid hamartoma identified with flexible bronchofiberscopic biopsies.

서 론

폐과오종은 양성종양 중에는 상당한 빈도률 차지하 지만, 전체 폐종양 중 빈도는 낮은 편이다 ${ }^{1)}$. 대부분 특별한 선행 증상없이 건강진단 등 우연히 촬영한 단 순 훙부 X-선 사진상에서 발견되는 경우가 많으며, 특 히 원발성폐암과의 감별진단이 용이치 않으므로 임 상 적으로 중요한 의미를 갖는다.

기관지내 발생한 과오종은 희귀하여 1972년까지 전 세계적으로 58예가 보고되어 있으며 ${ }^{2)}$, 기관지경으로 수술전 확진한 기관지내 과오종예는 더욱 희귀하다.
한양대학교 의과대학 내과학교실에서 굴곡성 기관지 경하 생검으로 확진한 연골성 과오종 1 예를 경험하였 기에 문헌고찰과 함께 보고하는 바이다.

$$
\text { 증 례 }
$$

환 자 : 장 $\bigcirc$ 순, 여자, 52 세

주 소 : 우측 훙부불쾌감, 기침, 고열

현병력 : 입원 2 개월전부터 고열 및 기침으로 인하여 타 병원에 입 원 굴곡성 기관지경 검사를 시행하였고 결핵으로 진단하여 INH, ethambutol, pyrazinamide kanamycin 으로 치료하였으나, 증상의 호전이 없어 본 


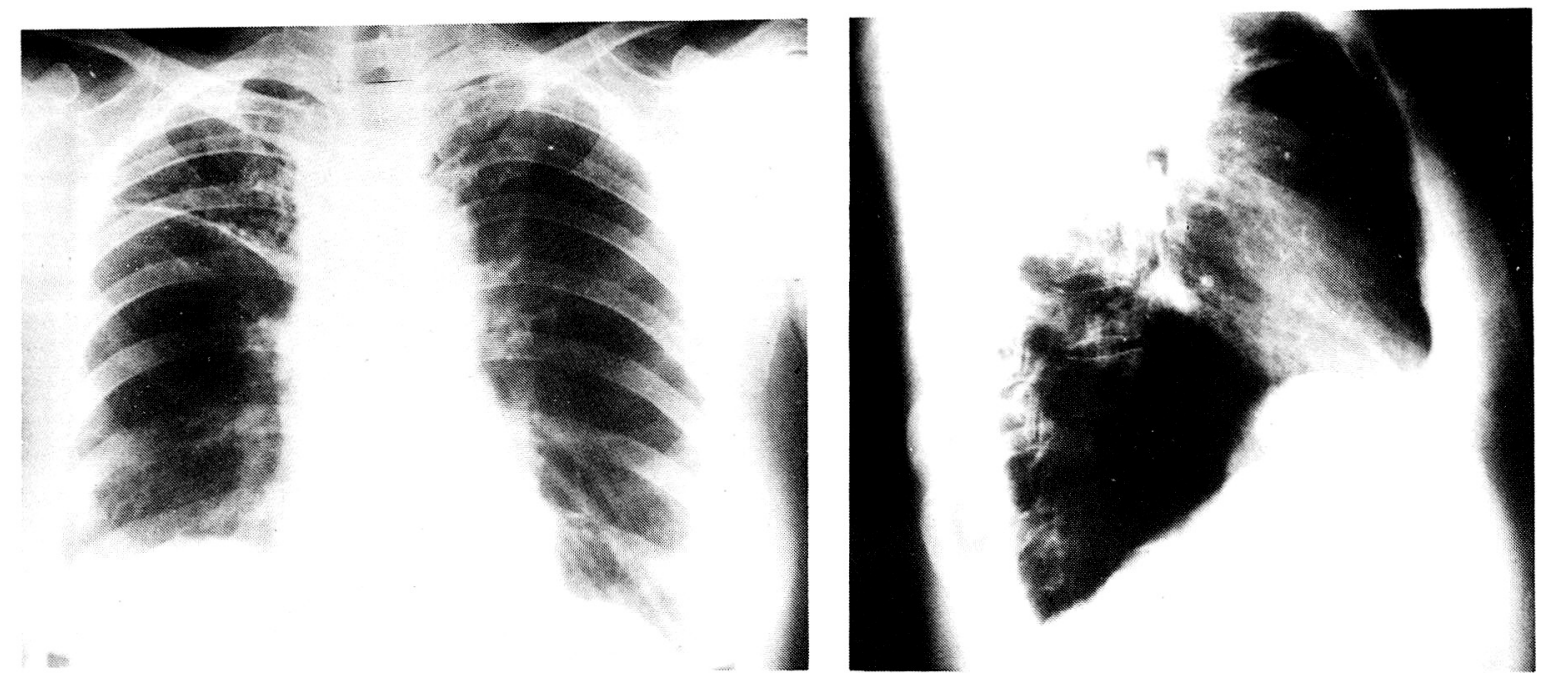

Fig. 1. Chest P-A and right lateral view show ill-defined mottled increased density in the right upper lung field with minor fissure elevation. Mottled calcifications are also in the left upper lung field.
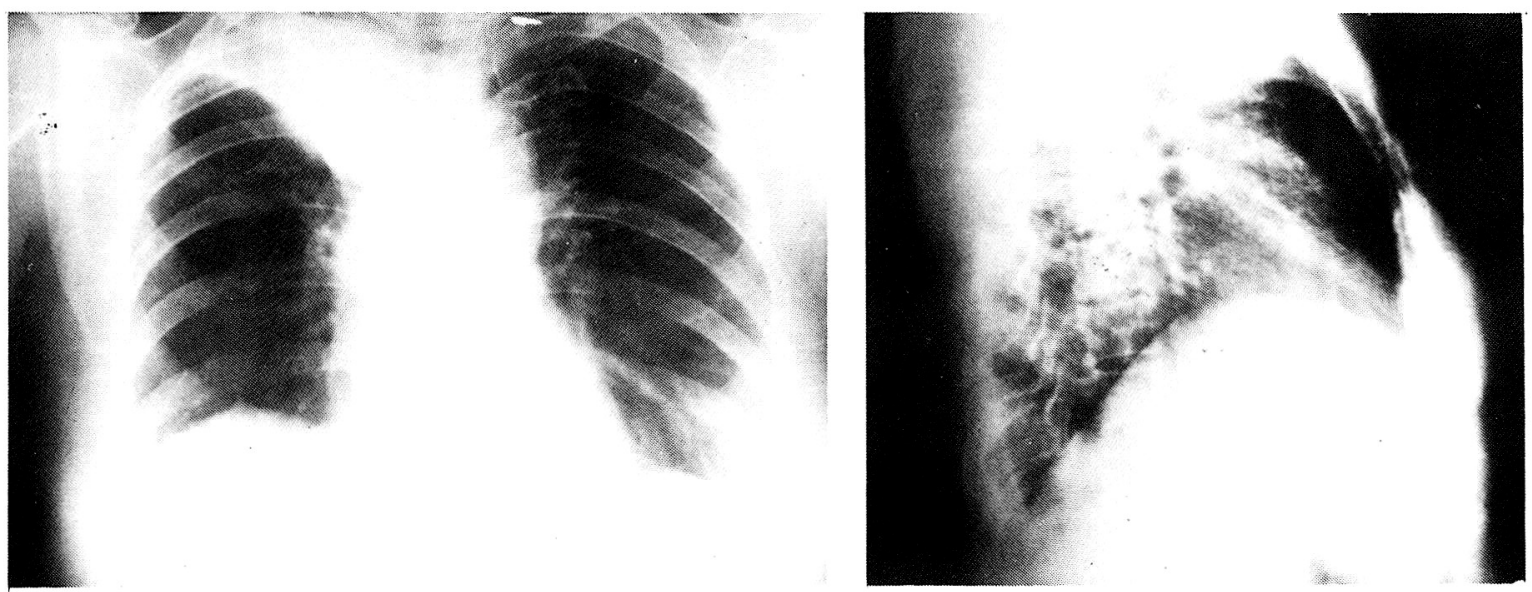

Fig. 2. Two weeks later, chest P-A and right lateral view show atelectasis with findings of increased density in the right upper lung field, loss of right lung volume and elevation of right diaphragm.

원 내과외래로 내원하였고, 외래에서 시행한 3 차례 객담 $\mathrm{AFB}$ 도말표본검사는 음성이었고, 결핵균에 대 한 배양검사상 성장결핵균주는 없었고 혈청 $\mathrm{CEA}$ 는 $2.3 \mathrm{ng} / \mathrm{ml}$ 였다. 기관지결핵 및 합병된 폐염, 폐암등 의 감별 진단을 위해 외래에서 굴곡성 기관지경 및 생 검을 실시 연골성 과오종으로 확진한 후 본원내과에 입 원하였다.

과거력: 30 년전 폐결핵의 기왕력으로 그 당시 항결 핵제 투여로 완치되었다. 과거 흡연 및 음주는 하지 않 았다.

가족력 : 특이사항 없음.

증 세 : 훙부불쾌감, 기침, 흰색의 객담, 발열, 체 중감소(한달간 $3 \sim 4 \mathrm{~kg}$ ), 오한

이학적 소견 : 입원당시 혈압은 $140 / 90 \mathrm{mmHg}$ 이었
고, 맥 박수 108 회/분, 호흡수 20 회/분, 체온은 $38.8^{\circ} \mathrm{C}$ 이었다. 입원당시 폐청진상 이상소견은 없었고, 기타 특이사항은 없었다.

입 원당시 검 사소견은 $\mathrm{Hb}: 13.1 \mathrm{gm} \%, \mathrm{Hct}: 37.7 \%$, WBC: $13,200 / \mathrm{mm}^{3}$, Polys: $85 \%$, Band neutrophils $: 3 \%$, Lymphocyte : $10 \%$, Monocyte : $2 \%$, 혈소판 $238,000 / \mathrm{mm}^{3}$, 적혈구 침강속도는 $28 \mathrm{~mm} / \mathrm{hr}$ 이었다. 뇨검사, 대변내 기생충 및 잠혈검사, 혈청전해질검사, 간기능 검사소견 모두 정상범위였다. 심전도 검사상 동 성빈맥소견이 관찰되었으며, 폐기능검사상 $\mathrm{FVC} 2.85 \mathrm{~L}$ (102.4\% of predicted value), $\mathrm{FEV}_{1} 2.22 \mathrm{~L}$ (97.8\% of predicted value), $\mathrm{FEV}_{1} / \mathrm{FVC} 78.04 \%(92.2 \%$ of predicted value), $\mathrm{FEF}_{25-75 \%} 2.11 \mathrm{~L} / \mathrm{S}(66.9 \%$ of predicted value)였다. 
방사선학적 검사 : 단순흥부후전 및 우측면 엑스런 진 (Fig. 1)상 소열구의 상위와 좌우 양상부 폐역에 불 분명한 반상의 석회침착소견을 나타닜으며, 우측상엽 부위에 부분적 허탈소견이 있었으며, 2 주후 추적엑스

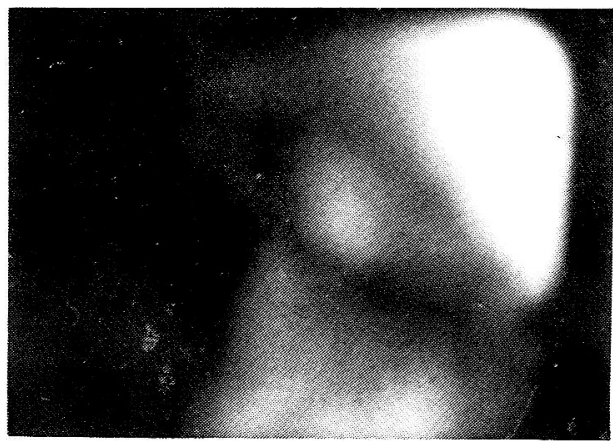

Fig. 3. Bronchofiberscopic finding: The right upper bronchus was obstructed by nodular, hard, yellowish-red mass, estimated $1 \times 2 \mathrm{~cm}$ in size.

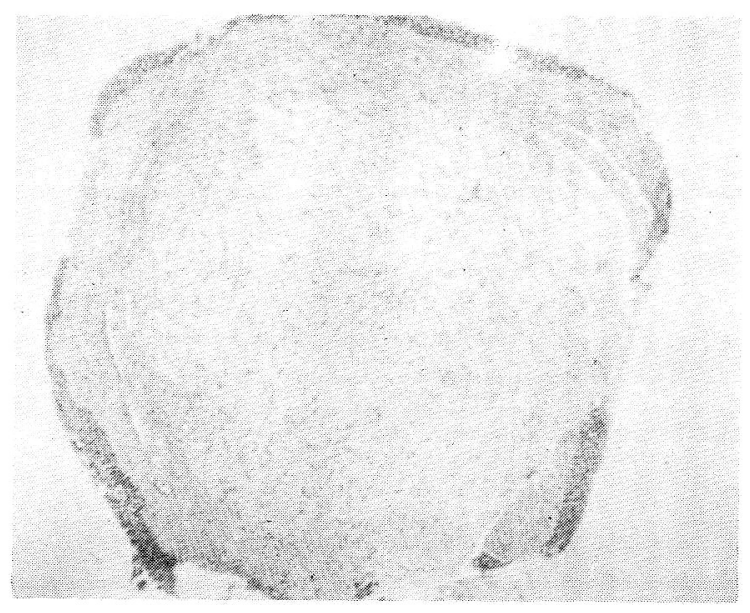

Fig. 4. Bronchofiberscopic biopsy reveals polypoid mass composed of loosely scattered bipolar or stellate mesenchymal cells in myxoid background. This mass transit to chondroid tissue (H-E, $\times 40)$.

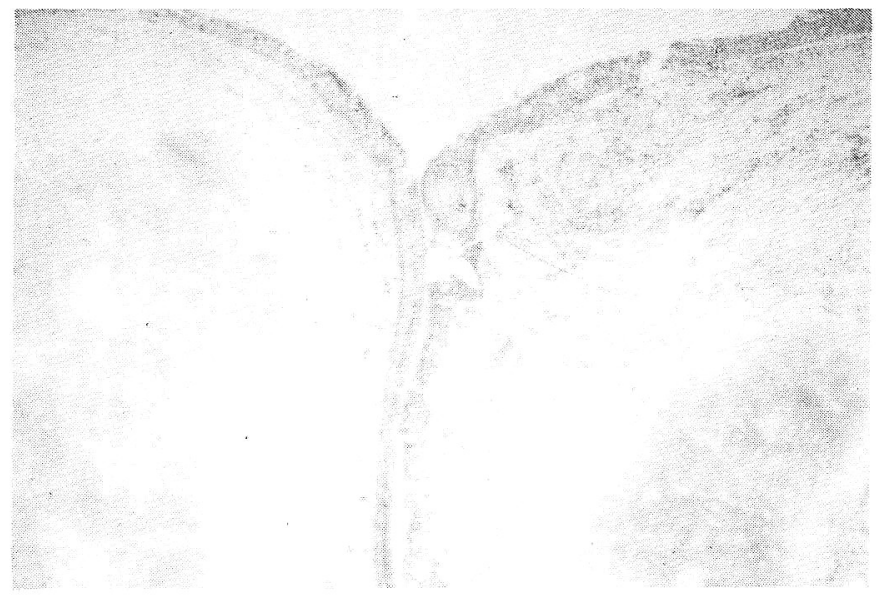

Fig. 5. Postoperative histologic finding: Two large cartilagenous islands on both sides are noted together with loose mesenchymal tissue at the periphery. Entrapped cleftlike space is lined by respiratory mucosa $(\mathrm{H}-\mathrm{E}, \times 40)$.

선사진(Fig. 2)상 진행되어 우측상엽 부위의 증가된 음영, 우측 폐용적 감소, 횡격막의 상위로 우측 상엽 부위의 무기폐 소견을 나타내고 있었다.

굴곡성 기관지경 검사 : 우측 상엽기관지가 $1 \times 2 \mathrm{~cm}$ 크기의 결절성 포면을 갖는 딱딱한 황적색 종괴에 의 하여 폐쇄되어 있었고(Fig, 3), 굴곡성 기관지세척 및 생검을 실시하였다. 기관지 세척액의 세포학적 검사 상 Class I 소견이었으며, 악성세포는 보이지 않았다.

수술 소견 : 우측 배후측흉부절개에 의한 우측상엽 절 제술을 시행하였다. 첨단부의 하측면표면은 중동도의 유착소견을 보였고, 우축상엽기관지는 종괵에 익하여 켸쇄되어 있었다.
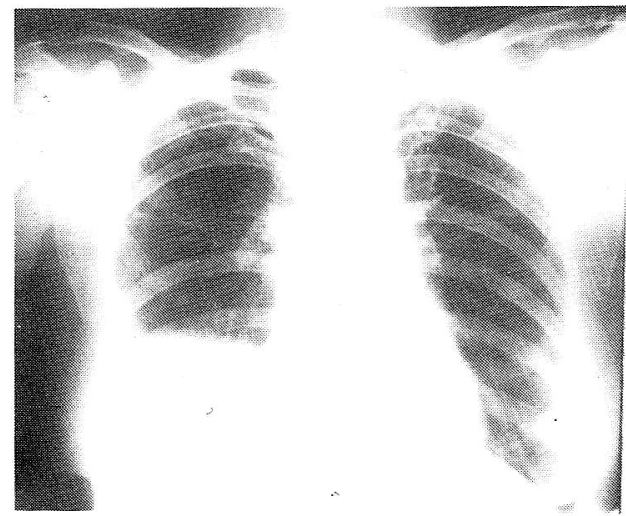

Fig. 6. Postoperative chest $\mathrm{X}$-ray shows pneumothorax in the right upper lung field. 


\section{병리학적 소견}

육안적 소견 : 종괴는 폴립양상을 나타냈고, 크기는 $1.8 \times 1.2 \times 0.8 \mathrm{~cm}$ 이었고, 표면은 회갈색이며, 분엽돼 있었다. 절단시 지리학적 백색연골섬들이 점액조직 사 이에 끼어들어 있었다.

기관지경하 생검의 현미경 소견 : 정상상피로 덮여 있 고, 내부에는 소성결합초직으로 구성된 간엽세포의 과 성장에 의한 종괴를 형성하였고, 폴립양상을 보이고 있 었다(Fig. 4).

수술후 현미경 소견 : 완전한 호흡상피를 볼 수 있었 고, 간엽조직내 연골섬이 있었으며, 호홉상피가 entrap 되어 있었다(Fig. 5).

수술후 경과 : 수술후 5 일째 우측폐상부에 약 $10 \%$ 의 기홍이 발생하였으나(Fig. 6), 완치되어 수술후 12일 째 퇴원하였다.

\section{고 찰}

1904년 Albrecht")은 간장에서 생긴 과오종을 "어떤 장기에서 정상적.으로 존재하는 성분이 비정상적으로 배합되어 생기는 종양과 같은 기형을 과오종이라 한다 고 정의하였고, 이러한 이상은 배태발육과정 동안 조직 의양, 배열, 분화정도에 있어서 변화된 형태를 보이며 비장, 유방 및 폐둥 다른 장기에서도 볼 수 있다고 하 였다. 콰오종의 발생기전은 변위된 기관지 배태잔유조 직에 의한 선천적기형, 겅상구조의 증식, 염 증기원의 종양, 양성 후천성종양등 원인에 대한 여러가지 이론 들이 있는데 ${ }^{(7)}$ Bateson $\left.^{8}\right)$ 은 노인의 폐에 발생한 과오 종에서 섬유성 결합조직이 원발성 종양조직이고, 연골 및 지방조직등 다른 결합조직은 이차적으로 형성된 것 으로 켸의 과오종은 기관지벽의 섬유성 결합조직 종양 이고, 상피는 기 관지점 막 표면상피의 봉입에 의하여 생 긴 것으로 섬유세포와 연골세포사이 점진적인 이행이 있다고 하였으며, 전자현미경에 의하여 증명되었다.9). 또한 유아의 폐에서 후에 과오종으로 진행될 만한 세 포간유물을 발견할 수 없고, 유아에서 폐의 과오종이 발생했다는 보고도 없으며, 대개 50 대 성인에서 발생 빈도가 높다는 점, 연속 $\mathrm{X}$-선촬영추적시 병소가 점차 커지는 점등 임상적, 조직 병리학적 방사선학적 연구결 과 발육이상으로 인한 병소는 아니고. 기관지벽의 결 합조직에서 후천적으로 발생한 양성종양인 것을 알 수 있다 ${ }^{8,10)}$. 과오종은 최근 30 여년간 그 조직의 구성성분 에 따라 chondroadenoma, hamartochondroma ${ }^{11}$, lipochondroadenoma ${ }^{12}$, adeno-lipo-fibro-osteochon- droma $^{13)}$ 및 chondromatous hamartoma 등 여러 명 칭으로 불리어지고 있으며, 현재에는 연골성 과오종 또 는 과오종의 명칭으로 주로 사용되고 있다. 폐과오종 은 폐병소의 약 $8 \%$ 를 점하며, 폐의 양성종양중 가장 흔한 종양이며 ${ }^{14)}, 10$ 년간 외과적 절제술을 시행하였 던 양성 폐종양 130 예 중 $76.9 \%$ 가 과오종이었으며 ${ }^{10)}$, 외과적 절제술을 시행하였던 고립성 뎨소결절의 $16 \%$ 를 점하였다 ${ }^{15)}$. McDonald 등 ${ }^{16)}$ 은 7,972명의 부검 중 $0.25 \%$ 에서 발견되었으며, 일반인구의 $0.25 \%$ 을 점한 다 ${ }^{17)}$. 남녀의 비는 $2.4: 1 \sim 4.5: 1$ 로 남자에 호발하 며 ${ }^{10,11,16,18,19)}$, 호발평균연령은 $50 \sim 60$ 세이다 ${ }^{10,11)}$. 기 관지내 과오종은 연골성 과오종의 8 20\%에서 발견되 며 ${ }^{11)}$, 조등 ${ }^{20)}$ 에 의하면 국내에는 5 예의 기 관지 과오종 이 보고되고 있다. 임상증상은 Arrigoni 등10)에 의하 면 100예의 폐과오종중 $40 \%$ 에서 호흡기증상을 나타냈 다 하였다. 32 예의 기관지내 과오종의 임 상증상중 기 침이 $84.4 \%$ 로 가장 많았고, 각혈 $34.4 \%$, 발열 $25 \%$,

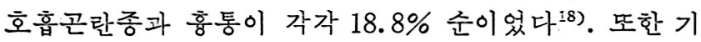
관지 폐쇄로 인하여, 분절 또는 대엽성폐기종이 발생 하고, 이후에 폐간질염, 무기폐, 기관지확장증으로 진 행할 수 있다 ${ }^{19}$. 26 예의 기관지내 과오종의 훙부X-선 소견상 무기폐가 $50 \%$ 로 가장 많았으며, 폐침윤 38.5 $\%$, 폐문종괴 $19.2 \%$ 순이었다 ${ }^{18}$. 본 증례예 있어서도 기침, 발열등 임상증상이 있었으며, 훙부X선상 무기폐 소견이 있었다. 폐과오종의 크기는 $0.5 \sim 30 \mathrm{~cm}$ 이고 ${ }^{14}$, 18), 중앙부위에 튀긴 옥수수같은 석희침착(popcorn like calcification)이 3 75\%에서 나타나고 ${ }^{14,19}$, 주 로 폐말초부위에 비교적 크기가 작은 단발성동전형병 변으로 단순흉부X선에서 우연히 발견되기 때문에, 다 른 폐종양, 특히 원발성 폐암과의 감별진단이 용이치 않으므로 임 상적으로 중요한 의미를 갖는다미. 그밖에 종격동내의 기형종, 기관지 선종, 근아세포종, 선종, 지 방종, 원주종, 혈관종, 섬유종, 순(純)연골종, 순(純) 골종과 감별진단을 요하며, 특히 부분적으로 석회침착 한 결핵성육아종과는 감별진단이 대우 어렵다 ${ }^{19}$. Ober 등21)은 성장기를 흰치 (displacement), 정상적으로 조 절된 성장기, 경도의 촉진된 성장기, 촉진된 급성장기 의 4 가지 성장기를 기술하였다. 병소의 성장속도는 일 년에 $1 \mathrm{~mm}$ 또는 그 이하로 진행되다. 때때로 년 $1 \mathrm{~cm}$ 또는 그 이상으로 빨리 진행된다 하였 고 ${ }^{22}$ Jensen 둥 ${ }^{23}$ 은 1년에 $0.5 \mathrm{~cm}$ 씩 성장한다 하였 고, Sagel 등24)은 16 개월내 본래 병소 크기의 3 배에 이른 과오종 1 예를 보 고 하였다. 기관지 조영술은 기관지내 과오종의 진단 에 유용한 방법 중 하나이며 2), 기 관지경 검사상 육안적 
으로 폐암과 감벌진단이 불가능하머, 적절한 조직을 얻을 수 있는 경우는 드물고, 기관지내 과오종은 수술 전 확진하는 경우가 매우 드물기 때문에, 보통은 개훙 술을 요한다 ${ }^{25)}$. 그러나 최근에 는 가능한한 불필요한 외과적 수술을 피한다는 의미에서 연령을 참고하여 경 피적 폐침생검이나 브러쉬생검 등으로 양성여부를 규 명코저 하고 있다리. 기관지내카오종의 발생부위 좌 측이 $54.5 \%$, 우측 $4.5 .5 \%$ 가 발생하고, 좌하엽기관 지에 가장 많이 발생한다. ${ }^{27)}$. Dovenbarger 등 ${ }^{18)}$ 은 28 예의 기관지내 과오종중 $19.4 \%$ 가 좌측 주기관지에 위 치하였고, 우측 주기관지와 우측폐하엽에 각각 $12.9 \%$ 발생하였다. 종괴의 육안적인 소견에서 분홍빛, 노란 빛 토는 척청색을 나타내며, 표면은 흴면, 분엽, 유두 의 양상을 나타내며, 경도는 연골, 지방, 결합조직의 상대배합양에 빠라 연질내지 단단하다 ${ }^{18)}$. 현미경소견 상 과오종의 $96 \%$ 가 연골성분으로 구성되어 있으며, 드 물게는 연골성분이 소성점액종간질과 지방조직내 점차 쇠퇴하면서, 연골점액성조직의 아주 작은 섬모양으로 표현된다. 성숙지 방이 주성분인 경우도 있고 점액성 결 합조직이 현저한 경우도 있다 ${ }^{10)}$. 다발성 과오종은 연 골은 결핍듸어 있고 주고 펑활근으로 구성되어 있어 평 활근종성 과오종이라 한다. 폐과오종은 2 가지로 분류 하는데, 첫째형은 선연골종 또는 연골성 과오종이라 하 며, 흔한형으로 기관지분아의 부조화 성장으로 인한 것 으로 생각되며, 연골의 응괴와 섬모상피로 덮인 열구 들을 포함하고, 주로 늑막주위에 위치하며 폐조직내 파 묻혀 있다. 둘째형은 부조화 간엽조직성 (disordered mesenchymal growth)에 의한 것으로 생각되고, 작 은 다발성 늑막하 병병으로 나타나고, 입방형상피로 덮인 미분화 간엽조직을 포함하는 낭포성 공간으로 구 성되어 있는데 점액을 분비하는 장관상피도 존재할 수 도 있닥). 과오종 절제술후 12 개월내 2예에서 폐암이 발생하였다는 보고가 있고 ${ }^{14)}$, Hayward 등 ${ }^{28)}$ 은 12예의 악성변화를 보고 하였으나, 연골성 과오종이 악성변화 를 하는 것인지 폐암과 과오종이 공존하는 것인지 논 란이 많으나, 과오종의 악성변화는 드문 것으로 되어 있다 ${ }^{7,28,29)}$. 과오종은 양성종양으로 이상적인 치료방 법은 기관지경하 제거, 기관지 절개술 및 절제술이지만 기관지내 과오종은 기관지 폐쇄로 인한 무기폐, 감염, 조직파괴를 방지하기 위하여, 드물게 악성변화 때문에 외과적으로 제거하여야 한다 ${ }^{18)}$.

\section{결 론}

한양대학교 내과학교실에 내 원한 52 세 여자환자에서
수술전 굴곡성 기관지경하생 검으로 기관지내 연골성 과오종으로 확진하여 우측 상엽절제술을 시행한 1 예를 경험하였기에 문헌고찰과 함께 보고하는 바이다.

\section{REFERENCES}

1) Carter D, Eggleston JC: Tumors of the lower respiratory tract, Fasclcle 17, Second series, Atlas of tumor pathology, Washington: Armed Forces Institute of Pathology 1979

2) Sibala JL: Endobronchial hamartomas. Chest 62:631, 1972

3) Albrecht E: Üeber Hamartome. Verh Deutsch Ges Path 7:153, 1904

4) Ehrenhaft JL, Womack NA: Mixed tumors of the lung. A reappraisal. Ann Surg 136:90, 1952

5) Chardack WM, White GL: Chondromatous hamartoma of main bronchus. Surgery $34: 92$, 1953

6) Karasik A, Modan M, Jacob CO, Lieberman Y: Increased risk of lung cancer in patients with chondromatous hamartoma. J Thorac Cardiovasc Surg 80:217, 1980

7) Baum GL, Wolinsky E: Textbook of Pulmonary Diseases, 3rd Ed., Boston: Little and Brown, 1983, p1097-1098

8) Bateson EM: So-called hamartoma of the lung: A true neoplasm of fibrous connective tissue of the bronchi. Cancer 31:1458, 1973

9) Stone FJ, Churg AM: The ultrastructure of pulmonary hamartoma. Cancer 39:1064, 1977

10) Arrigoni MG, Woolner LB, Bernatz PE, Miller WE, Fontana RS: Benign tumors of the lung: A ten-year surgical experience. J Thorac Cardiovasc Surg 60:589, 1970

11) Bateson EM: Relationship between intrapulmonary and endobronchial cartilage containing tumors (so called hamartomata). Thorax 20:447, 1965

12) Brewin EG: A case of lipoma of the bronchus. treated by transpleural bronchotomy. Brit $\mathrm{J}$ Surg 40:282, 1952

13) Peters $R$ : Ueber dar sogenannte Lungenchondrcm. Beitr Path Anat 89:484, 1932 quoted by 
Bazeson

14) Fudge TL, Ochsner JL, Mills NL: Clinical spectrum of pulmonary hamarotmas. Ann Thorac Surg 30:36, 1980

15) Hood RT, Good CA, Clagett OT, McDonald JR: Solitary circumscribed lesions of lung, study of 156 cases in which resection was performed. JAMA 152:1185, 1953

16) McDonald JR, Harrington SW, Clagett OT: Hamartoma (often called chondroma) of the lung 14:128, 1945

17) Young JM, Jones E, Hughes FA, Foley FE, Fox JR: Endobronchial hamartoma: Report of two cases. J Thorac Surg 27:300, 1954

18) Dovenbarger WV, Elstun W: Endobronchial hamartoma. Am J Med 30:965, 1961

19) Koutras P, Urschel HC, Paulson DL: Hamartoma of the lung. J Thorac Cardiovasc Surg $61: 768,1971$

20) 조규석, 박주철, 유세영 : 폐과오종. 대한흉부외과 학회지 18:470, 1985

21) Ober WB, Kaiser GA: Hamartoma of the par- athyroid. Cancer 11:601, 1958

22) Gluck MC, Moser KM: Hamartoma of the lung presenting as a mediastinal mass. Am Rev Resp Dis 98:281, 1968

23) Jensen KG, Schiodt T: Growth conditions of the lung. Thorax 13:133, 1958

24) Sagel SS, Ablow RC: Harmatoma: On occasion a rapidly growing tumor of the lung. Radiology 91:971, 1968

25) Lansden FT, Ankeney JI: Endobronchial hamartoma. Ann Thorac Surg 2:845, 1966

26) Lillington GA: The solitary pulmonary nodule. Am Rev Resp Dis 110:699, 1974

27) Zeidler D, Vogot-Moykopf I: Das Intrabronchiale Hamartochondrom: Symptomato logie and Therapie. Pneumonologie 146:178, 1971

28) Hayward RH, Carabasi RJ: Malignant hamartoma of the lung: Fact or fiction? J Thorac Cardiovasc Surg 53:457, 1967

29) Poulsen JT, Jacobsen M, Francis D: Probable malignant transformation of a pulmonary hamartoma. Thorax 34:557, 1979 